\title{
EFFECT OF STERILIZATION ON THE SURFACE PROPERTIES OF Ti6A17Nb ALLOY FEMORAL STEMS
}

\author{
VPLIV STERILIZACIJE NA POVRŠINSKE LASTNOSTI \\ FEMORALNIH KOLČNIH KOMPONENT ENDOPROTEZ IZ \\ Ti6A17Nb ZLITINE
}

\author{
Klemen Avsec ${ }^{1,2}$, Marjetka Conradi ${ }^{3}$, Monika Jenko ${ }^{3,4}$, Boštjan Kocjančič ${ }^{1,2}$, \\ Mojca Debeljak $^{5}$, Matevž Gorenšek ${ }^{6}$, Drago Dolinar ${ }^{1,2,3^{*}}$ \\ ${ }^{1}$ Department for Orthopaedic Surgery, University Medical Centre Ljubljana, Zaloška 9, 1000 Ljubljana, Slovenia \\ ${ }^{2}$ Faculty of Medicine, University of Ljubljana, Vrazov trg 2, 1000 Ljubljana, Slovenia \\ ${ }^{3} \mathrm{MD}-\mathrm{RI}$ Institute for Materials Research in Medicine, Bohoričeva 5, 1000 Ljubljana, Slovenia \\ ${ }^{4}$ Institute of Metals and Technology, Lepi pot 11, 1000 Ljubljana, Slovenia \\ ${ }^{5}$ University Rehabilitation Institute, Republic of Slovenia, Linhartova 51, 1000 Ljubljana, Slovenia \\ ${ }^{6}$ MD Medicina, Bohoričeva 5, 1000 Ljubljana, Slovenia \\ Prejem rokopisa - received: 2020-07-28; sprejem za objavo - accepted for publication: 2020-08-19
}

doi:10.17222/mit.2020.141

We investigated thirty retrieved femoral components (cement-less stems made from Ti6Al7Nb alloy) of prematurely failed hip endoprostheses, due to aseptic loosening, infection and low-grade infection and two new stems (after their expiry date) for comparison. The main aim was to find the impact of cleaning and sterilization procedures of new and retrieved stems on the surface properties, i.e., surface wetting, roughness and surface chemistry. Our hypothesis was that the effect of cleaning and sterilization should not affect the meaningful difference of surface properties of retrieved and new stems of hip cement-less endoprostheses. Clean, new and retrieved stems of hip endoprostheses were sterilized using classical steam autoclave AC, procedure protocol $\left(121^{\circ} \mathrm{C}, 1.25 \mathrm{bar}, 20 \mathrm{~min}\right)$. Surface wettability was determined by measuring the static contact angle of a water drop, the roughness was measured by optical 3D system. The surface chemistry was analysed by X-ray Photoelectron Spectroscopy (XPS). In wettability results, the contact angle varied from $70.6^{\circ}$ to $91^{\circ}$, and the surface roughness $\left(S_{\mathrm{a}}\right)$ varied from $4.2 \mu \mathrm{m}$ to $4.7 \mu \mathrm{m}$ for all thirty measured stems. We found that surface properties measured on three different stem positions (neck, middle and root) differ significantly, we can conclude that corundum $\left(\mathrm{Al}_{2} \mathrm{O}_{3}\right)$ grit-blasted surface used to obtain the necessary roughness for better osteointegration is not homogeneous. The XPS results of new and retrieved implants that prematurely failed for different reasons showed minor differences of $\mathrm{TiO}_{2}$ thin oxide native film thickness: $6.2 \mathrm{~nm}$ for the new stem and $5.2 \mathrm{~nm}$ for retrieved (prematurely failed due to aseptic loosening, infection or low grade infection, consisting primarily of $\mathrm{TiO}_{2}$ ). The results confirm our hypothesis that the effect of cleaning and sterilization on surface properties of new and retrieved stems is negligible.

Keywords: hip endoprostheses, stem, Ti6Al7Nb alloy, cleaning, steam autoclave sterilization, surface properties, wettability, roughness, XPS

Raziskali smo trideset uporabljenih femoralnih komponent brezcementnih endoprotez kolka iz Ti6Al7Nb zlitine, ki so predčasno odpovedale zaradi enega od sledečih najpogostejših vzrokov: aseptičnega omajanja, okužbe, nizke stopnje okužbe. Za primerjavo smo raziskali dve novi femoralni komponenti. Glavni namen raziskave je bil ugotoviti vpliv čiščenja in sterilizacije novih in uporabljenih femoralnih komponent na površinske lastnosti kot so: omočenje, hrapavost in površinska kemija. Naša hipoteza je bila, da vpliv čiščenja in sterilizacije bistveno ne vpliva na razlike površinskih lastnosti novih in uporabljenih femoralnih komponent kolčnih endoprotez. Ciste, nove in uporabljene femoralne komponente kolčnih endoprotez smo sterilizirali po klasičnem postopku v pari v avtoklavu (AC), po protokolu $\left(121{ }^{\circ} \mathrm{C}, 1.25\right.$ bar, 20 min). Omočljivost površine je bila določena $\mathrm{z}$ meritvami kontaktnega kota vodne kapljice, hrapavost je bila izmerjena z optičnim 3D sistemom na treh mestih in sicer na vratu, $v$ sredini in korenu femoralne komponente. Površino smo analizirali $z$ rentgensko fotoelektronsko spektroskopijo (XPS). Rezultati omočljivosti, merjeni na treh različnih mestih (vrat, sredina, koren), na vseh tridesetih femoralnih komponentah brezcementnih endoprotez kolka, so sledeči: kontaktni kot od $70.6^{\circ}$ do $91^{\circ}$; hrapavost $\left(S_{\text {a }}\right)$ od $4,2 \mu \mathrm{m}$ do $4,7 \mu \mathrm{m}$. Rezultati omočljivosti in hrapavosti, merjeni na treh različnih mestih novih in uporabljenih femoralnih komponent, kažejo opazne razlike, iz česar lahko sklepamo, da površina obdelana s peskanjem s korundnimi delci $\left(\mathrm{Al}_{2} \mathrm{O}_{3}\right), \mathrm{ki}_{\mathrm{j}}$ je potrebna $\mathrm{za}$ boljšo osteointegracijo, ni homogena. Rezultati XPS-analize površine novih in uporabljenih vsadkov, ki so predčasno odpovedali zaradi različnih vzrokov, kažejo minimalne razlike $\mathrm{v}$ debelini $\mathrm{TiO}_{2}$ : pasivne tanke oksidne plasti $6,2 \mathrm{~nm}$ za nove vsadke in $5,2 \mathrm{~nm}$ za uporabljene, ki so predčasno odpovedali zaradi aseptičnega omajanja, okužbe ali nizke stopnje okužbe. Dobljeni rezultati potrjujejo našo hipotezo, da je vpliv čiščenja in sterilizacije na površinske lastnosti novih in uporabljenih vsadkov, zanemarljiv.

Ključne besede: kolčne endoproteze, Ti6Al7Nb zlitina, čiščenje, sterilizacija v avtoklavu, površinske lastnosti, omočljivost, hrapavost

\section{INTRODUCTION}

Total hip joint arthroplasty (THA) is the most successful surgical method for relieving pain, correcting de-

*Corresponding author's e-mail:

dolinardrago@gmail.com (Drago Dolinar) formities and treating degenerative hip-joint disease and trauma $^{1-7}$ The Ti6Al7Nb alloy is the most commonly used metallic implant material for the femoral stem and the acetabular cup of hip endoprostheses, and has been in clinical use since 1986. ${ }^{1-6}$ The Ti6Al4V alloy, as we have already described in our previous paper, ${ }^{8}$ has been the most popular metallic implant material used in THA 
1
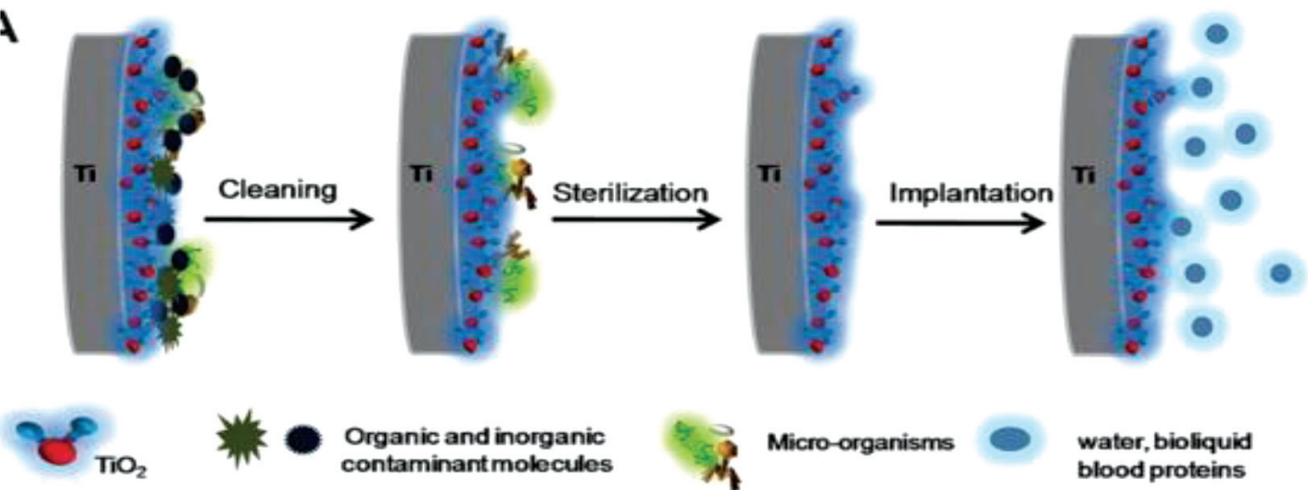

Organic and inorganic contaminantmolecules

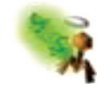

water, bioliquid blood proteins

Figure 1: Outline of procedures at the Ti alloy surface during cleaning, sterilization, and implantation, adapted from J. H. Park et al. ${ }^{17}$

(and is still widely used in the USA), but in recent decades Ti6Al7Nb has become a very popular material because of its better biocompatibility due to the replacement of vanadium (toxic when released over certain critic levels) with niobium.

The surface roughness of the cementless stem of a hip endoprosthesis is very important for good osseointegration. With the aim of improving the osseointegration of orthopaedic implants, many surface-modification strategies have been developed, focusing on the biomaterial surface properties and health costs. ${ }^{9-13}$

Corundum-grit blasting is the most widely used mechanical surface treatment for roughening the surfaces of titanium cementless implants due to its good surface-roughening properties. Corundum-grit blasting introduces contamination of the surface of the Ti6Al7Nb alloy implant due to retained corundum, which can adversely affect the osseointegration process of the implant. This is in addition to the roughening effects and the source of the wear particles that could cause debris-related aseptic loosening. ${ }^{14-16}$

The retrieved biomaterial devices, i.e., femoral metallic components of hip endoprostheses, that are stored for the investigation of premature failures, etc., must be cleaned and sterilized.

Park et al. ${ }^{17}$ reported on the effects of cleaning and sterilization and presented a graphic illustration of processing of biomaterials from cleaning to implantation (Figure 1).

The cleaning procedure removes or reduces the visible contamination (blood, protein and debris) on the surface, while the sterilization stops the reproduction of micro-organisms, bacteria, spores and fungi. ${ }^{17-23}$ The following sterilization methods are in use nowadays for different materials such as Gama irradiation GR (25KGy), Steam autoclave AC $121{ }^{\circ} \mathrm{C}, 1.24$ bar, $20 \mathrm{~min}$, Oxygen plasma (OP) and Ultarviolet (UV) $254 \mathrm{~nm}$ for 90 minutes. ${ }^{17}$

The cleaning and sterilization influence the properties of new and retrieved Ti6Al7Nb alloy surfaces, which were studied to find possible changes in terms of wettability, roughness, morphology, microstructure, corrosion and surface chemistry. ${ }^{17-20}$

A major responsibility of healthcare providers is to minimize patient risks. Therefore, they require additional attention to the sterilization and quality control process.

According to the US Food and Drug Administration (FDA), an implant/implantable device is a "device that is placed into a surgically or naturally formed cavity of the human body" Ideally, implants and implantable devices should come individually wrapped and sterile from the manufacturer.

The surface roughness of a cementless stem is very important for the good osseointegration of the implant. In order to enhance the osseointegration of orthopaedic implants, many surface-modification strategies have been tried, focusing on the important role of the biomaterial's surface properties. ${ }^{9-13}$

Grit blasting using corundum or alumina is a commonly used surface treatment for roughening the surfaces of titanium cementless implants.

In the present study the surface properties, in terms of wettability, roughness and morphology of retrieved and new femoral components, i.e., the stems, of cementless hip endoprostheses, were studied in detail with the aim to find differences in the surface properties of new and

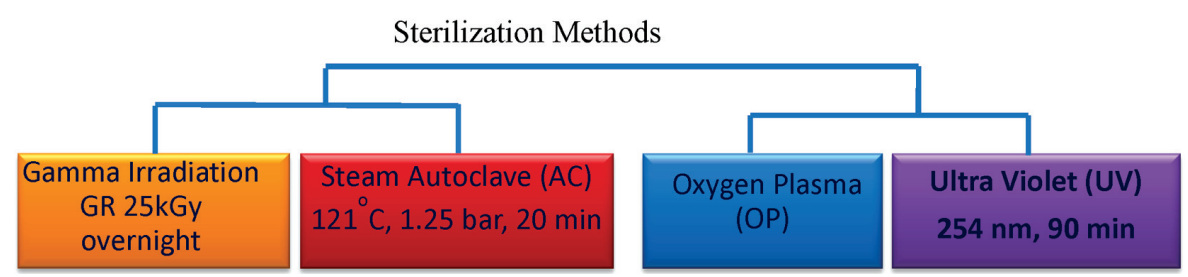

Figure 2: Sterilization methods: gamma irradiation ( $25 \mathrm{kGy}$ overnight), steam autoclave $\left(121^{\circ} \mathrm{C}\right.$ at 1.25 bar, $\left.20 \mathrm{~min}\right)$, oxygen plasma and ultra violet $(254 \mathrm{~nm}, 90 \mathrm{~min})$ 
retrieved femoral components after cleaning and sterilization.

The main aim is that our results from retrieved implants can be used as the base knowledge for the improvement of existing and the development of new procedures and manufacturing of better implants with better longevity.

Our hypothesis is that the effect of cleaning and sterilization on surface properties of new and retrieved stems is negligible.

\section{MATERIALS AND METHODS}

\subsection{Implants/stems}

The retrieved Ti6Al7Nb stems of the cementless hip endoprostheses were selected from revision surgeries performed at the Department for Orthopaedic Surgery of the University Medical Centre (UMC) Ljubljana (Ljubljana, Slovenia). We also investigated two new stems (after their expiry date) for comparison.

For this investigation, 30 stems of cementless hip endoprostheses that prematurely failed due to:

1) aseptic loosening (10 implants),

2) infection (10 implants) and

3) latent infection (10 implants) were selected.

The interval between the primary hip replacement and the revision surgery was 36 months to 239 months for aseptic loosening, 3 months to 36 months for infection and 36 months to 168 months for latent infection.

Knowledge of the behaviour of individual prosthesis in certain clinical conditions is very important. We have selected for detailed investigation the cementless Zweymuller-ZM type hip endoprostheses, new and retrieved, that prematurely failed due to aseptic loosening, infection and latent infection. Figure 3 shows the stems of different hip endoprostheses manufacturers.

The retrieved stems were ZM type from an unknown manufacturer, while the new ones were Smith and Nephew (London, UK) Ti6Al7Nb stems of cement-less



Figure 3: ZM type of cementless femoral component hip endoprostheses of Ti6Al7 $\mathrm{Nb}$ alloy new, and retrieved femoral stems used in our research hip endoprostheses. After the revision surgery, the retrieved implants were sent for sonication in Ringer's solution and afterwards for cleaning and sterilization. All the retrieved stems were cleaned according to standard procedures at UMC Ljubljana, which consist of immersion in $2 \%$ microsoap solution, followed by acetone, isopropanol $(\mathrm{xN}), 95 \%$ ethanol $(\mathrm{xN})$, and deionized water $(\mathrm{xN}) ;(\mathrm{xN})$ is the number of repeated processes. Sterilization was performed by autoclaving according to a standard protocol at $120{ }^{\circ} \mathrm{C}$ and a pressure of 1.25 bar for $20 \mathrm{~min}$. Afterwards, sterilized stems were kept in sterile bags in a dry place for further investigations. New femoral components were cleaned and sterilized at the manufacturer's site and the special bags were opened on site just before the implantation. The cleaning and sterilization processes, according to the literature data and our experiences, do not affect the removal of the particle debris. ${ }^{10-15}$ The chemical compositions of the new and retrieved implants were determined by X-ray fluorescence (XRF, Niton XL3t GOLDD+, Thermo Scientific, Waltham, MA, USA) and inductively coupled plasma atomic emission spectroscopy (ICP-AES, Agilent 720, Agilent Technologies, Santa Clara, CA, USA) chemical analyses. The results of the measurements (Ti 87.8, Al 5.6, $\mathrm{Nb} 6.4, \mathrm{Fe} 0.21, \mathrm{Cr} 0.007$, Ta 0.02 in mass \%) were in good agreement with the requirements of the ASTM F1295-05 Standard Specification for Wrought Titanium-6 Aluminum-7 Niobium Alloy for Surgical Implant Applications. ${ }^{24}$

Samples for the investigation of the surface properties (wettability, roughness) and morphology using scanning electron microscopy (SEM - ZEISS crossbeam 550 FIB-SEM, Carl Zeiss AG, Oberkochen,Germany) were prepared from the new and retrieved stems, cleaned in an ultra-sonic bath of isopropyl alcohol and dried in dry nitrogen gas. The samples for the surface-chemistry analyses of the passive film had polished surfaces.

\subsection{Wettability}

The static-water contact-angle measurements on the as-received and sterilized stems were performed at three characteristic sites (at the root, in the middle and at the neck) using a surface-energy evaluation system (Advex Instruments r.o.). Water droplets of $5 \mu \mathrm{L}$ were deposited on the surface and the average contact angle was determined using Young-Laplace fitting from at least five measurements on each characteristic site. The measurements were carried out at $20{ }^{\circ} \mathrm{C}$ and an ambient humidity of $55 \%$. An optical 3D metrology system, Alicona Infinite Focus (Alicona Imaging $\mathrm{GmbH}$, Raaba, Austria), was employed for the surface-roughness measurements on the as-received and sterilized stems at three characteristic sites (at the root, in the middle and at the neck). Three measurements were performed at each site using a magnification of $20 \times$ with a lateral resolution of $0.9 \mu \mathrm{m}$ and a vertical resolution of about $50 \mathrm{~nm}$. Subsequently, 
the IF-Measure Suite (Version 5.1) software was used for an evaluation of the average surface roughness, $S_{\mathrm{a}}$ :

$$
S_{\mathrm{a}}=\frac{1}{L_{x}} \frac{1}{L_{y}} \int_{0}^{L_{x}} \int_{0}^{L_{y}}|z(x, y)| \mathrm{d} x \mathrm{~d} y
$$

where $L_{x}$ and $L_{y}$ are the $x$ and $y$ acquisition lengths of the surface and $z(x, y)$ is the height. The size of the analysed area was $714 \mu \mathrm{m} \times 542 \mu \mathrm{m}$.

\subsection{Surface chemistry - XPS analysis}

The samples for XPS studies were cut from new and retrieved stems, grinded and polished and exposed for $24 \mathrm{~h}$ at room temperature to the air.

The X-ray photoelectron spectroscopy (XPS) analyses were carried out on a PHI-TFA XPS spectrometer from Physical Electronics Inc. USA. Samples were polished before the analyses and exposed to the air for one day. The native oxide layer was analyzed for thickness and composition on two Ti6Al7Nb samples. The analysed area was $0.4 \mathrm{~mm}$ in diameter and the analyzed depth was about $3-5 \mathrm{~nm}$. This high surface sensitivity is a general characteristic of the XPS method. Sample surfaces were excited by X-ray radiation from a monochromatic Al source at a photon energy of $1486.6 \mathrm{eV}$. Quantification of the surface composition was performed from the XPS peak intensities, taking into account the relative sensitivity factors provided by the instrument manufacturer. ${ }^{24-26}$ We estimate that the relative error of the calculated concentrations is about $20 \%$ of the reported values. In order to analyze the in-depth distribution of elements in the sub-surface region up to $25 \mathrm{~nm}$, XPS depth profilling was performed in combination with argon-ion sputtering. Ar ions of energy $3 \mathrm{keV}$ were used. The velocity of the ion sputtering was estimated to be $1.0 \mathrm{~nm} / \mathrm{min}$, calibrated on a $\mathrm{Ni} / \mathrm{Cr}$ multilayer structure of known thickness.

\section{RESULTS AND DISCUSSION}

\subsection{Wettability and roughness}

To analyse the surface wettability, we performed five static contact-angle measurements with water at three characteristic spots on each stem: neck, middle and root. We determined the average contact-angle values at each

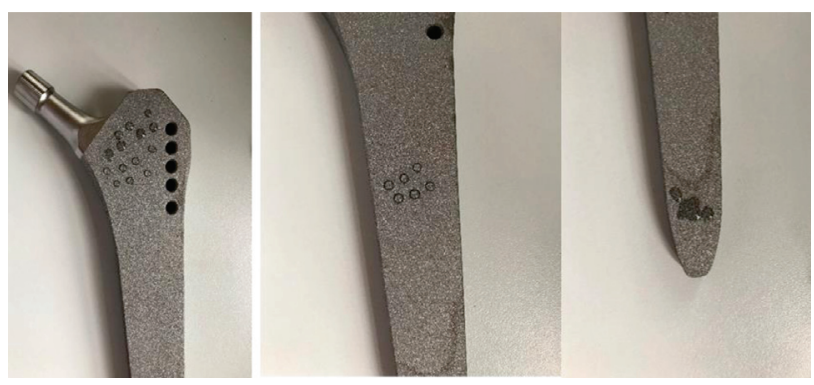

Figure 4: Static water contact-angle measuring site on new stem site with an estimated error in the reading of $\theta \pm 2.0^{\circ}$. The average surface-roughness parameter was used to evaluate the morphological characteristics of the stems and the three sites of the measurements.

Contact-angle and average-surface-roughness measurements at the three characteristic sites on a new stem before and after sterilization are shown in Table 1. We can see that the new stem is moderately hydrophobic and the wettability is practically the same at all three sites. Sterilization, however, turns the surface of the stem hydrophilic. Interestingly, there is a large difference in the wettability between the three sites, the root being strongly hydrophilic compared to the middle and the neck (Figure 4 and Table 1).

Table 1: Static-water contact angles $\theta$ and average surface roughness, $\mathrm{S}_{\mathrm{a}}$, of a new Ti6A17Nb stem (Smith \& Nephew) N1 before and after sterilization.

\begin{tabular}{|c|c|c|c|}
\hline & & $\begin{array}{c}\text { before steril- } \\
\text { ization }\end{array}$ & $\begin{array}{c}\text { after steriliza- } \\
\text { tion }\end{array}$ \\
\hline Implant N 1 & $S_{\mathrm{a}}(\mu \mathrm{m})$ & $\Theta(\mathrm{deg})$ & $\Theta(\mathrm{deg})$ \\
\hline Site 1 & 5.209 & 116.3 & $66.5(49-85)$ \\
\hline Site 2 & 5.884 & 114.8 & 73.7 \\
\hline Site 3 & 5.570 & 115.9 & 36.8 \\
\hline
\end{tabular}

The average surface roughness is of the same order for all three sites and is not affected by the sterilization.

We performed additional surface analyses on the neck, middle and root of the used stems. Contact-angle



Figure 5: Static contact-angle measurements of prematurely failed hip endoprostheses due to: a) aseptic loosening, b) infection and c) latent infection: there is no large difference regarding the cause of premature failure (Table 2)

Table 2: Static-water contact angles $\theta$ and average surface roughness, $S_{\mathrm{a}}$, of prematurely failed hip endoprostheses due to: a) aseptic loosening, b) infection and c) latent infection

\begin{tabular}{|c|c|c|}
\hline a) & $S_{\mathrm{a}}(\mu \mathrm{m})$ & $\theta\left(^{\circ}\right)$ \\
\hline Neck & $4.3 \pm 0.1$ & $82.5 \pm 1.5$ \\
\hline middle & $4.2 \pm 0.3$ & $80.4 \pm 2.1$ \\
\hline Root & $4.3 \pm 0.1$ & $81.3 \pm 1.4$ \\
\hline b) & & $82.1 \pm 2.1$ \\
\hline Neck & $4.6 \pm 0.2$ & $86.9 \pm 1.3$ \\
\hline middle & $4.6 \pm 0.2$ & $91.6 \pm 1.9$ \\
\hline Root & $4.7 \pm 0.1$ & \\
\hline c) & & $80.4 \pm 1.9$ \\
\hline Neck & $4.5 \pm 0.1$ & $70.6 \pm 1.8$ \\
\hline middle & $4.5 \pm 0.2$ & \\
\hline
\end{tabular}

Materiali in tehnologije / Materials and technology 55 (2021) 1, 59-64 
and average-surface-roughness measurements of the prematurely failed hip endoprostheses due to aseptic loosening, infection and latent infection are shown in Table 2. The results show that there is no noticeable difference regarding the cause of premature failure due to these reasons. All the surfaces are poorly hydrophilic close to the hydrophobic regime and there is no significant difference in the average surface roughness at different sites and on different stems.

Surface-roughness measurements of a new hip cementless Zweymüller stems of three different producers: a) Smith \&Nephew $S_{\mathrm{a}}=6.7 \mu \mathrm{m}$, b) Alloclasic varial $S_{\mathrm{a}}=5.0 \mu \mathrm{m}$ and c) Alloclasic Zweymüller $S_{\mathrm{a}}=4.7 \mu \mathrm{m}$, measured by Alicona instrument described in our previous paper. ${ }^{14}$

\subsection{XPS surface analysis}

When exposed to air or water at room temperature, titanium alloys spontaneously form thin $\mathrm{TiO}_{2}$ oxide films (a passive film) of 4-6 nm thickness immediately. A stable, thin oxide film protects the Ti alloys from pitting, intergranular and crevice corrosion and are responsible for the excellent biocompatibility.

XPS depth profiles of native oxide film that forms on the fresh surface, after grinding and polishing and exposure to the air for $24 \mathrm{~h}$ of new and retrieved stems are shown in Figures 6 and 7. The oxide layer on the new and retrieved samples consisted of Ti-oxide, Al-oxide and $\mathrm{Nb}$-oxide. This was evidenced by the Ti $2 \mathrm{p}_{3 / 2}$ peak at $458.6 \mathrm{eV}$, characteristic for $\mathrm{Ti}(4+)$ in a $\mathrm{TiO}_{2}$-like environment, the $\mathrm{Nb} 3 \mathrm{~d}_{5 / 2}$ peak at $207.0 \mathrm{eV}$, characteristic for the $\mathrm{Ni}(5+)$ oxidation state, and the $\mathrm{Al} 2 \mathrm{p}$ peak at $74.0 \mathrm{eV}$, characteristic for the $\mathrm{Al}(3+)$ oxidation state.

In our recent preliminary investigation of retrieved implants that prematurely failed for different reasons (aseptic loosening, infection, latent infection) using the surface-analysis method XPS, we noticed minor differences and proceeded with a detailed investigation of the implant surfaces prematurely failed due to aseptic loosening, infection and low-grade infection.

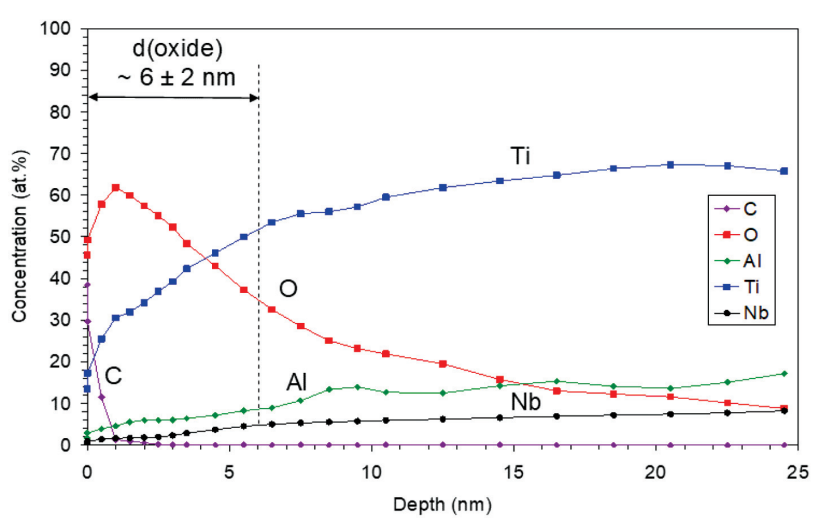

Figure 6: XPS depth profile of a new Ti6A17Nb alloy covered with native oxide after polishing. Thickness of the oxide was estimated to be $6 \pm 2 \mathrm{~nm}$

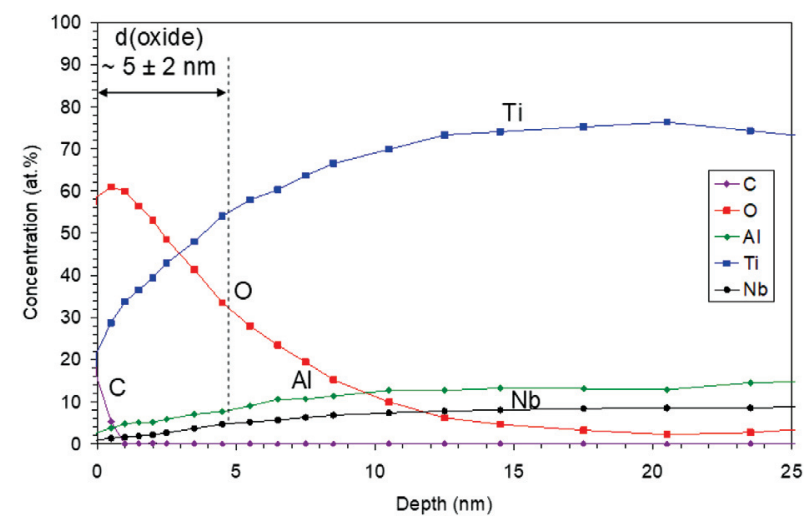

Figure 7: XPS depth profile of a retrieved Ti6Al7Nb alloy covered with a native oxide after polishing. The thickness of the oxide was estimated to be $5 \pm 2 \mathrm{~nm}$

\section{CONCLUSIONS}

The present study establishes the effect of cleaning and sterilization on the surface properties of the new and retrieved femoral components of a Ti6Al7Nb alloy of cementless hip endoprostheses that were provided by the Orthopaedic Clinic of the University Medical Centre Ljubljana.

We found that sterilization, steam autoclaving at $121^{\circ} \mathrm{C}, 1.25 \mathrm{bar}$, for 20 minutes, affects the wetting properties of the new and retrieved Ti6Al7Nb alloy, turning the initially moderately hydrophobic stem to hydrophilic. The analyses of retrieved stems showed the poorly hydrophilic nature of all the samples, regardless of the failure.

The thicknesses of the thin oxide films on the Ti6Al7Nb (primarily of $\mathrm{TiO}_{2}$ ) were estimated using XPS depth profiling. The $\mathrm{Ti}, \mathrm{O}, \mathrm{Al}, \mathrm{C}$ and $\mathrm{Nb}$ peaks were detected in the XPS analysis. The estimated oxide thickness of new implant was $6.2 \mathrm{~nm}$ and $5.2 \mathrm{~nm}$ for retrieved one, consisting primarily of $\mathrm{TiO}_{2}$.

The results confirm our hypothesis that the effect of cleaning and sterilization on surface properties of new and retrieved stems is negligible.

\section{Acknowledgement}

This research was funded by the Slovenian Research Agency Grant ARRS (P2-0132 Institute of Metals and Technology) and Tertiary Projects of the Department of Orthopaedic Surgery of University Medical Centre Ljubljana UKCLJ20180128 and UKC20190145.

\section{REFERENCES}

${ }^{1}$ S. Kurtz, K. Ong, E. Lau, F. Mowat, M. Halpern, Projections of primary and revision hip and knee arthroplasty in the United States from 2005 to 2030, J. Bone Joint Surg. Am., 89 (2007) 780-785

${ }^{2}$ M. J. Grimm, Standard Handbook of Biomedical Engineering; McGraw-Hill, New York, USA, 2004 
${ }^{3}$ L. C. Jones, L. D.Timmie Topoleski, A. K.Tsao, Biomaterials in orthopedic Implants, Edt Elizabeth Friis; Mechanical testing in Orthopedic Implants, 2017, WP, Elsevier, doi:10.1016/B978-0-08100286-5.00002-0

${ }^{4}$ D. Dolinar, M. Gorenšek, M Jenko, M. Godec, B. Šetina, Č. Donik, A. Kocijan, M. Debeljak, B. Kocjančič, Biomaterials in endoprosthetics, Mater. Tehnol., 52, (2018)1, 89-98, doi:10.17222/mit. 2017.196

${ }^{5}$ B. Mavčič, S. Roškar, V. Antoič, Clinical outcomes of titanium alloy SL-Plus femoral stem (Zweymuller): 2,013 total hip arthroplasty cases with 25 years of follow-up, $3^{\text {rd }}$ International Symposium on Biomaterials, October 16-17, 2019, Portorož, 3ISB Abstract booklet IMT

${ }^{6}$ M. J. Yaszemski, D. J. Trantolo, K. U. Levandrowski, V. Hasirci, D. E. Altobelli, Biomaterials in Orthopedics; CRC Press, New York, USA, 2003

${ }^{7}$ M. Merola, S. Affatato, Materials for Hip Prostheses: A Review of Wear and Loading Considerations, Materials, 12 (2019) 495

${ }^{8}$ M. Jenko, M. Gorenšek, M. Godec, M. Hodnik, B. Šetina, Č. Donik, J. T. Grant, D. Dolinar, Surface chemistry and microstructure of metallic biomaterials for hip and knee endoprostheses, Appl. Surf. Sci., 427 (2018) 584-593 doi/10.1016/japsuc2017

${ }^{9}$ D. V. Kilpadi, J. J. Weimer, J. E. Lemons, Effect of passivation and dry heat-sterilization on surface energy and topography of unalloyed titanium implants, Colloids Surfs, A 135 (1998) 89-101

${ }^{10}$ J. Göske, W. Uter, H. U. Ulrich, W. Kachler, G. Zeiler, A. Schuh, Surface Characterization of Corundum Blasted Implants in Hip Arthroplasty, Microsc. Microanal. 2004, 18, 9-11

${ }^{11}$ R. K. Alla, K. Ginjupalli, N. Upadhya, M. Shammas, R. K. Ravi, R.Sekhar, Surface Roughness of Implants: A Review, Trends Biomater. Artif. Organs., 25 (2011) 112-118

${ }^{12}$ C. Y. Guo, J. P. Matinlinna, J. K. H.Tsoi, Residual Contaminations of Silicon-Based Glass, Alumina and Aluminum Grits on a Titanium Surface After Sandblasting, Silicon 2015, 1-8

${ }^{13}$ D. Bitar, J. Parvizi, Biological response to prosthetic debris, World J. Orthop., 6 (2015), 172-189

${ }^{14}$ K. Avsec, M. Jenko, M. Conradi, A. Vesel, M. Mozetič, B. Kocjančič, D. Dolinar, Effect of autoclave or plasma oxygen gaseous sterilization on surface properties of cementless TiAl7Nb hip endoprostheses, $3^{\text {rd }}$ International Symposium on Biomaterials, October 16-17 2019, Portorož, 3ISB Abstract booklet IMT
${ }^{15}$ K. Avsec, M. Jenko, M. Conradi, A. Kocijan, A. Vesel, J. Kovac, M. Godec, I. Belic, B. Š. Batic, C. Donik, M.Gorenšek, B. Kocjancic, D. Dolinar, Surface Properties of Retrieved Cementless Femoral Hip Endoprostheses Produced from a Ti6Al7Nb Alloy, Coatings, 9 (2019) 868; doi:10.3390/coatings 9120868

${ }^{16}$ D. Dolinar, M. Jenko, M. Godec, M. Gorenšek, K. Avsec, B. Pompe, A. Cör, B. Kocjančič, Particulate debris from corundum-blasted titanium alloy cementless hip endoprostheses effecting aseptic loosening, AAOS 2020 Annual meeting, March 24-28,2020, Orlando Florida, E-presentation (no.) 626

${ }^{17}$ J. H. Park, R. Olivares-Navarrete, R. E. Baier, A. E. Meyer, R. Tannenbaum, B. D. Boyan, Z. Schwartz, Effect of cleaning and sterilization on surface properties and cell response of titanium alloy implant surface, Acta Biomater., 8 (2012)5, 1966-1975

${ }^{18}$ H. H. Tuson, D. B. Weibel, Bacteria-surface interactions, Soft Matter., 14 (2013) 9, 4368-4380, doi:10.1039/C3SM27705D

${ }^{19}$ W. A. Rutala, D. J. Weber; Disinfection and sterilization: An overview, American Journal of Infection Control, 41 (2013) 52-55

${ }^{20}$ B. Kausemo, J. Lausmaa, Biomaterial and implant surface - on the role of cleanliness, contamination, and preparation procedures, J. Biomed. Mater. Res. A, 22 (1988), 145-158

${ }^{21}$ M. Raphel, S. B. Holodniy, S. C. Goodman, C. Heilshorn, Multifunctional coatings to simultaneously promote osseointegration and prevent infection of orthopaedic implants. Biomaterials, 84 (2016) 301-314

${ }^{22}$ A. G. Gristina, Biomaterial-centered infection: microbial adhesion versus tissue integration. Science 237 (1987) 1588-1595

${ }^{23}$ P. Cools, N. De Geyter , E. Vanderleyden , P. Dubruel, R. Morent, Surface Analysis of Titanium Cleaning and Activation Processes,Non-thermal Plasma Versus Other Techniques, Plasma Chem Plasma Process, 34 (2014), 917-932, doi 10.1007/s11090-0149552-2

${ }^{24}$ ASTM F1295-05.Standard Specification for Wrought Titanium-6 Aluminum-7 Niobium Alloy for Surgical Implant Applications. (UNS R56700), https://infostore.saiglobal.com/store/details.aspx/ details.aspx?ProductID=249286 (10.06.2017).

${ }^{25}$ D. Briggs, J. T. Grant,. Surface Analysis by Auger and X-ray Photoelectron Spectroscopy Surface Spectra; IM Publications: Manchester, UK, 2003

${ }^{26}$ W. D. Kenton, B. A. Childs, A. Carlson, A. Lori, J. F. La Vannier, D. F. Moulder, Handbook of Auger Electron Spectroscopy; Physical Electronics: Eden Prarie, MN, USA, 1995

${ }^{27}$ J. F. Moulder, P. E. Sobol, Handbook of X-ray Photoelectron Spectroscopy; Physical Electronics:Eden Prarie, MN, USA, 1995 